\section{Spatial and temporal variation in nitrogen and phosphorus concentrations in faeces from springbok in the Kalahari}

\author{
F. Hein Stapelberg', Margaretha W. van \\ Rooyen ${ }^{1 *}$ \& Jacobus du P. Bothma ${ }^{2}$ \\ ${ }^{1}$ Department of Botany, University of Pretoria, Pretoria, \\ 0002 South Africa \\ ${ }^{2}$ Centre for Wildlife Management, University of Pretoria, Pretoria \\ Received 26 April 2007. Accepted 27 July 2007
}

The nutritional status of springbok, Antidorcas marsupialis, in the Kalahari was assessed in four habitats and three seasons by means of faecal profiling. Habitat only had a significant effect on the faecal nitrogen concentration in the cold-dry season, whereas faecal phosphorus concentrations showed no significant differences across habitats within a season. Seasonal differences in faecal nitrogen and phosphorus concentrations were more pronounced than habitat differences. Both faecal nitrogen and phosphorus concentrations differed significantly seasonally in the Nossob riverbed and in the dunes. Faecal concentrations of phosphorus and nitrogen were similar to that of springbok in other areas, but faecal nitrogen and phosphorus were below the critical range during the cold-dry season in the dune habitat and at a critically low level in the Nossob riverbed. Springbok in the southwestern Kalahari may experience nutritional stress during the dry winter period, especially in the interior dune fields.

Key words: faecal nitrogen, faecal phosphorus, Kalahari, springbok.

\section{INTRODUCTION}

Animal productivity is directly linked to the nutritional status of the population (Wrench et al. 1997; Van der Waal et al. 2003), which in turn depends on the intake of digestible energy and nutrients through food plants (Skarpe \& Bergström 1986). Common problems that hamper the determination of diet quality and animal condition include animal selectivity, and the cost, ethics and duration of using intrusive methods such as oesophageal fistulae (Leslie \& Starkey 1985; Wrench et al. 1997; Botha \& Stock 2005). These factors make dietary quality one of the most difficult aspects of range

*To whom correspondence should be addressed

E-mail: gretel.vanrooyen@up.ac.za nutrition to study (Wofford et al. 1985). Consequently, surrogate measures have been investigated to provide a cost-effective, indirect estimate of range nutrition and animal condition.

It has been demonstrated that faecal nitrogen and phosphorus concentrations can be used as indicators of the nutritive intake of a herbivore (Belonje 1978; Belonje \& Van den Berg 1980; Holechek et al. 1985; Grant et al. 1996; Wrench et al. 1997; Botha \& Stock 2005) and that comparing the faecal components of animals in different habitats could be of assistance in understanding their nutritional ecology (Erasmus et al. 1978; Wofford et al. 1985; Wrench et al. 1997; Van der Waal et al. 2003). Researchers have used faecal nutrient concentration studies in a variety of indigenous types of wildlife as well as for domestic livestock (Erasmus et al. 1978; Belonje \& Van den Berg 1980; Holechek et al. 1982, 1985; Wofford et al. 1985; Leslie \& Starkey 1985; Leite \& Stuth 1990; Irwin et al. 1993; Grant et al. 1995, 1996, 2000; MacLeod et al. 1996; Vorster 1996; Wrench et al. 1996, 1997; Van der Waal et al. 2003; Codron et al. 2005; Botha \& Stock 2005; Mbatha \& Ward 2006).

Leslie \& Starkey (1985) found that faecal nitrogen concentration increases with an increase of the nitrogen concentration of the herbivore's diet. Total faecal nitrogen is reported to correlate with the soluble nitrogen fraction in faeces (Leite \& Stuth 1990) although the ratio of insoluble nitrogen in faeces increases as the forage quality decreases (Leite \& Stuth 1990). The faecal nitrogen concentration of herbivores is considered to be a reliable predictor of pasture digestibility, provided that the diet consists primarily of grasses which have similar chemical properties, but it is less effective when the diet consists primarily of browse (Holecheck et al. 1982; Wofford et al. 1985; Grant et al. 1996). Tannins are reported to affect faecal nitrogen measurement (Hobbs 1987; Wrench et al. 1997; Grant et al. 1995, 1997, 2000). However, the findings of other researchers contradict this relationship and describe the effect of tannins on faecal nitrogen as insignificant or minimal (Wrench et al. 1997; Van der Waal et al. 2003). It has also been argued that free-ranging herbivores avoid plants with high levels of phenolic compounds or low-quality browse (Leslie \& Starkey 1987; Irwin et al. 1993; Grant et al. 2000; Botha \& Stock 2005). Faecal phosphorus concentration is not affected by the tannin content of the herbivore's diet (Mbatha \& Ward 2006). Therefore faecal nitrogen and phosphorus should be considered together, 
because faecal phosphorus can aid in the interpretation of faecal nitrogen changes.

An investigation into the seasonal changes in nitrogen and phosphorus contents of selected plant species in the southwestern Kalahari showed that the overall nutritional value of the plant species was low (Stapelberg 2007). The crude protein content was found to be at or below ruminant requirements in the cold-dry season for the grass species in some habitats and the phosphorus content was below ruminant requirements in all plant species, in all habitats during the cold-dry season. However, as ungulates have the ability to select the most nutritious plants or plant parts available (Mbatha \& Ward 2006) determining diet quality of free-ranging animals on the basis of nutrient levels in forage is unreliable (Grant et al. 2000). In the present study faecal analysis was used as a cost-effective and non-invasive method to investigate the nutritional status and diet quality of the springbok, Antidorcas marsupialis, in the southwestern Kalahari. We tested whether or not faecal nitrogen and faecal phosphorus concentrations varied by season and habitat and whether they fell below critical maintenance values for ruminants in some seasons.

\section{STUDY AREA}

The study area is located on the South African side of the Kgalagadi Transfrontier Park, a large conservation area within the southwestern Kalahari which is spread across the borders of South Africa and Botswana. The region is classified as an arid savanna (Van Rooyen \& Van Rooyen 1998) and is characterized by deep aeolian sand (Totolo \& Chanda 2003). The park contains a range of plant communities and plant associations but most herbivores concentrate in the Auob and Nossob riverbeds (Mills \& Retief 1984). The mean annual rainfall in the study area as measured at the Nossob, Mata-Mata, and Twee Rivieren rest camps and the town of Van Zylsrus from 1980 to 2005 was $180.4 \mathrm{~mm}$ (electronic data supplied by the South African Weather Bureau 2005), with the bulk of this highly variable rain occurring in summer. Three ecological seasons occur, known as the hot-wet (January to April), cold-dry (May to August) and hot-dry seasons (September to December) (Leistner 1967; Mills \& Retief 1984; Van Rooyen \& Van Rooyen 1998).

\section{MATERIALS AND METHODS}

Faecal samples were collected from springbok on the South African side of the Kgalagadi Transfrontier Park in four different habitats viz. the Auob riverbed, the Nossob riverbed, the pans and the dunes. Sampling was done in the hot-wet season (April 2003), in the cold-dry season (July/ August 2003), and in the hot-dry one (November 2003). Sampling was done at random and depended on encountering springbok en route between destinations. Wherever possible, five repetitions per habitat and per season were collected.

However, springbok were not encountered in the pans and dunes in all seasons. Faecal samples were either collected from single animals, or samples from different individuals within a herd were pooled into one. Faecal samples from immature springbok were only included if they had been weaned. Only fresh faecal samples of less than ten minutes old were collected to avoid the effects of exposure on the nutrient contents (Wrench et al. 1996). Samples were not collected if it rained, because rain has been found to decrease the phosphorus concentration of faeces by leaching (Wrench et al. 1996). Samples were placed in marked paper bags and were later oven dried in a convection oven at $80^{\circ} \mathrm{C}$ to a constant mass.

After drying the samples, they were milled through a $1 \mathrm{~mm}$ screen and sent to the University of Pretoria's Nutrilab for analyses. All chemical analyses were done in duplicate, according to the guidelines of the Association of Official Analytical Chemists (Cunniff 1990). The faecal nitrogen (N) concentration was determined using the macroKjeldahl method with a Tector Kjeltec system model 1002. Faecal phosphorus concentrations $(\mathrm{P})$ were determined with the standard spectrophotometer technique, using a Technicon Auto Analyzer II. Faecal nitrogen and faecal phosphorus are both reported as a percentage of the dry matter by mass. The mean nitrogen content can be multiplied by a factor of 6.25 to get a crude protein value (Boyazoglu 1997).

After testing for normality, data were analysed using SAS ${ }^{\circledast}$ software (Version 8.2, The SAS Institute Inc., Cary, U.S.A., running under z/VM 4.4.0 (RSU 0404) on the mainframe computer IBM Z800 2066/0C1 of the University of Pretoria). One-way ANOVAs were performed to compare the mean faecal nitrogen and phosphorus concentrations across seasons as well as habitats. In the figures the outcome of the seasonal comparisons within a habitat are given by the letters $a, b$ and $c$, whereas the outcome of the comparisons across habitats 


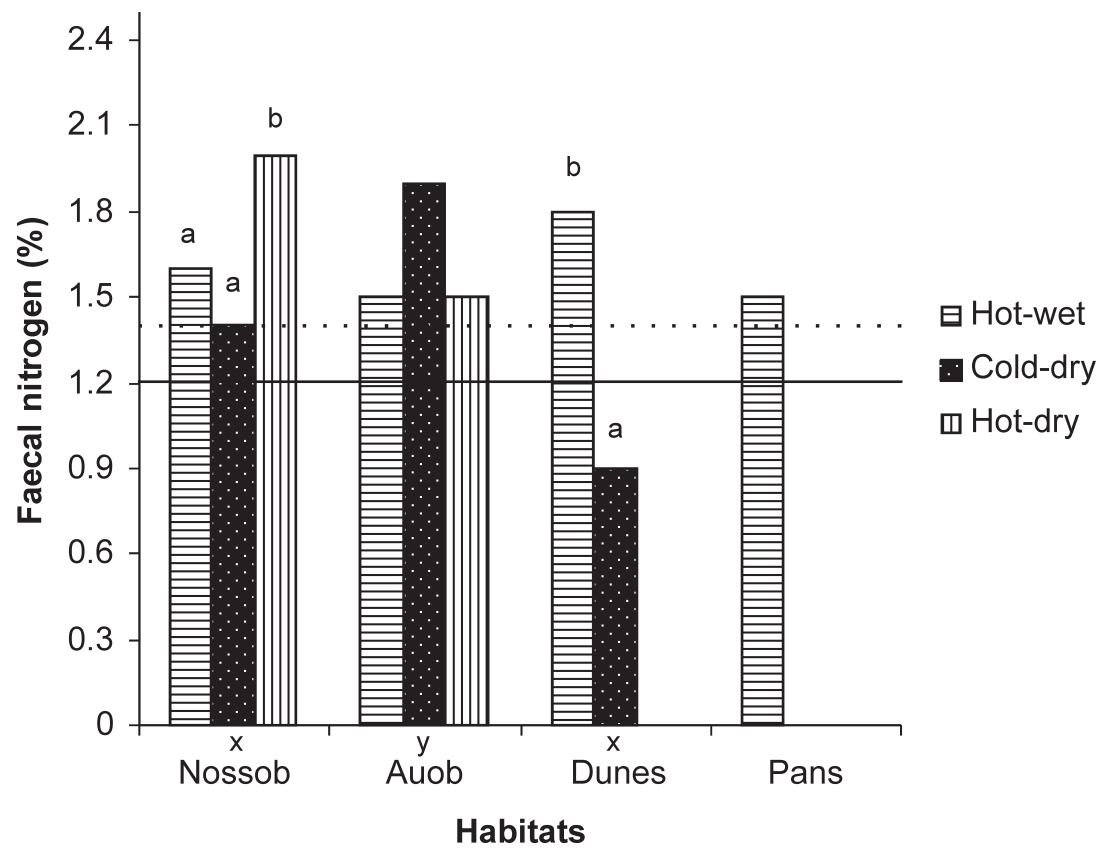

Fig. 1. Faecal nitrogen concentration of springbok on the South African side of the Kgalagadi Transfrontier Park, during the hot-wet, cold-dry and hot-dry seasons from April to November 2003. Concentrations are reported as a percentage of the dry matter by mass. The letters $a$ and $b$ above the bars denote significance in the same habitat between different seasons and the letters $x$ and $y$ below the bars denote significance in the same season between different habitats. Values with the same letters do not differ significantly $(P \geq 0.05)$. The solid line indicates the critical faecal nitrogen concentration suggested by Grant et al. (1995) and the dotted line the critical faecal concentration suggested by Wrench et al. (1997).

within a season are given by the letters $\mathrm{x}, \mathrm{y}$ and $\mathrm{z}$. The least square means were used for collective data.

\section{RESULTS AND DISCUSSION}

None of the collected samples showed any signs of dung beetle activity. In the present study, springbok in the southwestern Kalahari had a mean faecal nitrogen concentration of $1.6 \%$ of the dry matter by mass (standard deviation \pm 0.3 ) with a twofold range from $0.9 \%$ to $2.0 \%$. The mean faecal phosphorus content was $0.35 \%$ (standard deviation \pm 0.16 ) with a fourfold range from $0.15 \%$ to $0.67 \%$. Significant seasonal differences in faecal nitrogen content were found within the Nossob riverbed and in the dunes (Fig. 1). Habitat significantly affected faecal nitrogen contents in the cold-dry season, when faecal nitrogen concentrations were significantly higher in the Auob riverbed than in the Nossob riverbed or in the dunes, but habitat had no effect on faecal nitrogen concentrations in the other seasons. Faecal phosphorus also showed significant seasonal variation. In both the Nossob riverbed and dunes the values of the cold-dry season were significantly lower than the hot-wet season and in the Nossob riverbed the value in the hot-dry season was significantly higher than in the other seasons (Fig. 2). Faecal phosphorus was not significantly affected by habitat in any season.

An inverse relationship exists between the protein and fibre content of food plants and when the protein content of a food plant falls below $4-8 \%$ it becomes uneconomical for herbivore digestion (MacLeod et al. 1996). Grant et al. (1995) described a critical faecal nitrogen concentration for ruminants of $11-12 \mathrm{~g} / \mathrm{kg}$ dry matter (1.1-1.2\%) to maintain rumen fermentation, but suggested that short grass feeders, selective feeders and browsers seldom reach this critical level. Wrench et al. (1997) suggested a critical faecal nitrogen concentration for grazers of $14 \mathrm{~g} / \mathrm{kg}$ dry matter ( $1.4 \%$ of the dry matter by mass) to be associated with crude protein deficiency. Grant (et al. 2000) proposed that faecal nitrogen concentrations within the range $13-16 \mathrm{~g} / \mathrm{kg}(1.3-1.6 \%$ of the dry matter by mass) are above the threshold that indicates a dietary deficiency which may cause 


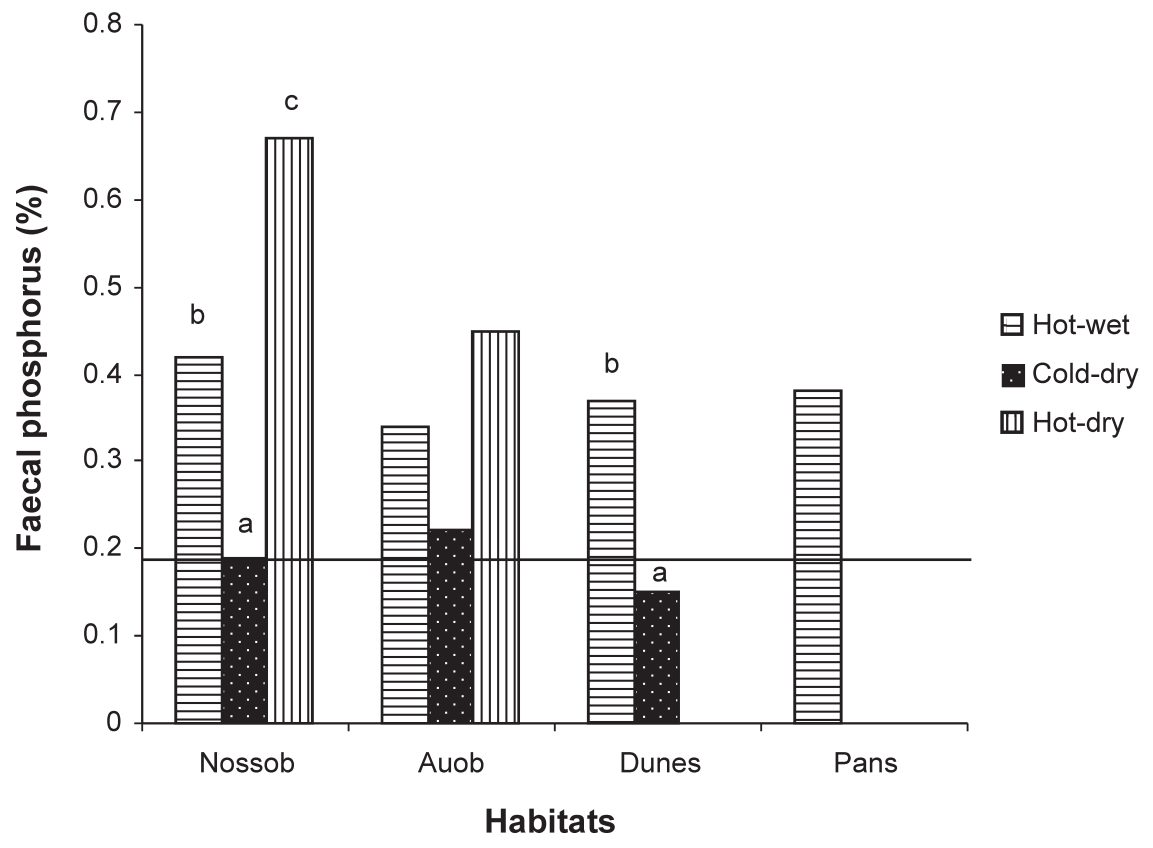

Fig. 2. Faecal phosphorus concentration of springbok on the South African side of the Kgalagadi Transfrontier Park, during the hot-wet, cold-dry and hot-dry seasons from April to November 2003. Concentrations are reported as a percentage of the dry matter by mass. The letters $a, b$ and $c$ above the bars denote significant differences in phosphorus concentration in the same habitat between different seasons. No significant differences were found in phosphorus concentration between habitats in the same season. Values with the same letters do not differ significantly $(P \geq 0.05)$. The solid line indicates the critical faecal nitrogen concentration suggested by Grant et al. (2000).

nutritional stress in animals. With the exception of the faecal nitrogen in the cold-dry season in the dunes, all values exceeded the critical levels proposed by Grant et al. (1995) and the value for the cold-dry season in the Nossob riverbed equalled the critical value proposed by Wrench et al. (1997).

The mean faecal nitrogen concentration in the present study was higher than that measured for blue wildebeest, Connochaetes taurinus, and African buffalo, Syncerus caffer, but lower than that reported for impala, Aepyceros melampus, kudu, Tragelaphus strepsiceros, and giraffe, Giraffa camelopardalis, in the Kruger National Park (Grant et al. 1995, 2000; Wrench et al 1996; Van der Waal et al. 2003), and nyala, Tragelaphus angasii, and impala in the Hluhluwe-Umfolozi Park (Botha \& Stock 2005). These comparisons indicate that the faecal nitrogen concentration of the springbok lies between that of bulk grazers (African buffalo and blue wildebeest) and strict browsers (kudu and giraffe). This finding supports the observed mixed feeding status of springbok in the southwestern Kalahari.

It has been found that elevated levels of faecal nitrogen may occur during a dry season due to the secretion of urea through the intestinal wall back into the gut lumen (Thornton et al. 1970). Higher levels of faecal nitrogen may also be due to a shift in the feeding strategy of a mixed feeder, changing its diet to include more browse food plants than grasses during the winter months (Mbatha \& Ward 2006). It is possible that the significantly higher faecal nitrogen concentration of springbok in the Nossob riverbed during the hot-dry season (Table 1) may be due to either of these factors, but the latter is a more likely explanation. The correlation between faecal nitrogen concentration and dietary quality deteriorates when dietary nitrogen levels are $>2.4 \%$ ( $>15 \%$ crude protein) of the dry matter by mass (Wofford et al. 1985; Irwin et al. 1993). The browse species that were examined in the present study frequently exceeded this value, although the grasses did not (Stapelberg 2007; Stapelberg et al., in press). The mixed feeding status of the springbok in the present study therefore complicates the interpretation of their faecal nitrogen levels. However, the fact that the faecal phosphorus was also high in the hot-dry season seems to indicate that the springbok were ingesting a higher quality diet. 
Phosphorus, and to some extent nitrogen, are deficient in most natural pastures (Grant et al. 1996; Wrench et al. 1997; Boomker 2002). However, a low faecal phosphorus concentration may be indicative of a low phosphorus intake or of efficient phosphorus utilization (Grant et al. 1995). Wrench et al. (1997) described a critical faecal phosphorus concentration of $2.0 \mathrm{~g} / \mathrm{kg}(0.2 \%)$ for most herbivore species. More recently, Grant et al. (2000) reported that a faecal range of between 1.9 and $2.0 \mathrm{~g} / \mathrm{kg}$ phosphorus over a long period of time leads to deficiencies in animals and hence to reduced production. In the present study, springbok in the southwestern Kalahari had faecal phosphorus levels below $1.9 \mathrm{~g} / \mathrm{kg}(0.19 \%)$ of the dry matter only during the cold-dry season in the dunes $(0.15 \%)$, while the faecal phosphorus in the Nossob riverbed reached a low of $0.19 \%$ in that season.

An investigation into the seasonal changes in phosphorus contents of selected plant species in the southwestern Kalahari showed that the food plant species also reached their lowest phosphorus levels during the cold-dry season (Stapelberg 2007; Stapelberg et al., in press), a time when their phosphorus concentration fell below the $0.18 \%$ minimum required by ruminants for maintenance (McDowell 1992, 1997) in all habitats for all plant species examined. The phosphorus concentration of the grass species in the present study was lower than the requirements for the maintenance of a ruminant in all seasons. This year-round phosphorus deficiency in grass species was not reflected in the faecal phosphorus concentrations, indicating the ability of springbok to select the most nutritious plant species or plant parts available and a preference for those habitats with food of a higher nutritional quality (Mills \& Retief 1984). Phosphorus deficiency is usually noticeable by symptoms such as pica (Boomker 2002). However, pica has not yet been reported in wildlife in southern Africa (Grant et al. 2000).

The mean faecal nitrogen content $(1.6 \%)$ in springbok in the present study was similar to that reported for springbok in a South African arid savanna elsewhere (Mbatha \& Ward 2006) and in the Karoo (Vorster 1996). The research of Erasmus et al. (1978) on springbok faecal nitrogen concentration could not be used for comparative purposes, as it did not involve free-ranging animals selecting their own diet. Similarly, the mean faecal phosphorus content of $0.35 \%$ of the dry matter by mass is similar to that of springbok on Pniel Estates within the arid savanna in South Africa (Mbatha \& Ward 2006) and springbok in the Karoo (Vorster 1996).

\section{CONCLUSIONS}

Faecal analysis proved to be an efficient, costeffective and non-invasive way to gather information on the diet quality of springbok in the Kalahari. Seasonal effects on the faecal nutritional status of springbok populations were stronger than the habitat effects in the present study. The faecal nutritional status in different habitats only differed significantly for the nitrogen concentration in the cold-dry season. Seasonal differences in faecal nutritional status were observed for both nitrogen and phosphorus concentration in the Nossob riverbed and in the dunes. It was found that the faecal concentration of phosphorus and nitrogen were similar to that of springbok in other arid savanna areas and based on faecal crude protein content, the mixed feeding guild of springbok was confirmed.

The mean faecal nitrogen (1.6\%) and phosphorus content $(0.35 \%)$ of springbok in the southwestern Kalahari over the entire study period were not lower than the proposed critical levels. However, in some instances faecal phosphorus and nitrogen concentrations were at or below the critical threshold in the cold-dry season. Although faecal nitrogen and phosphorus concentrations in the hot-wet and hot-dry seasons indicate that nitrogen and phosphorus intake is sufficient, the low values in the cold-dry season suggest that the diet of the springbok is not sufficient during this period in the dune habitat and is at a critically low level in the Nossob riverbed.

\section{ACKNOWLEDGEMENTS}

We thank Camelbak International for their support and Adriaan and Angela Badenhorst, Konrad du Plessis and Louis Olivier for their assistance with field work. The assistance of Mike van der Linde and Hennie Groeneveld with the statistical analyses is greatly appreciated. We express our gratitude towards the Kgalagadi Transfrontier Park for approving this project and the University of Pretoria and the National Research Foundation (GUN 2053522) for financial support.

\section{REFERENCES}

CUNNIFF, P. (Ed.) 1990. Official methods of analysis of Association of Official Analytical Chemists International (15th edn). AOAC International, Arlington, Virginia.

BELONJE, P.C. 1978. An investigation into possible 
methods of assessing the intake of calcium and phosphorus by grazing sheep. Onderstepoort J. Vet. Res. 45: 7-22.

BELONJE, P.C. \& VAN DEN BERG, A. 1980. The use of faecal analyses to estimate the phosphorus intake by grazing sheep. I. The use of pool instead of individual samples. Onderstepoort J. Vet. Res. 47: 163-167.

BOOMKER, J. 2002. Other diseases. In: Bothma, J. du P. (Ed.) Game ranch management, 4th edn. Van Schaik, Pretoria.

BOTHA, M.S. \& STOCK, W.D. 2005. Stable isotope composition of faeces as an indicator of seasonal diet selection in wild herbivores in southern Africa. S. Afr. J. Sci. 101: 371-374.

BOYAZOGLU, P.A. 1997. Animal nutrition: concepts and application. Van Schaik, Pretoria.

CODRON, D., CODRON, J., LEE-THORP, J.A., SPONHEIMER, M. \& DE RUITER, D. 2005. Animal diets in the Waterberg based on stable isotopic composition of faeces. S. Afr. J. Wildl. Res. 35: 43-52.

ERASMUS, T., PENZHORN, B.L. \& FAIRALL, N. 1978. Chemical composition of faeces as an index of veld quality. S. Afr. J. Wildl. Res. 8: 19-24.

GRANT, C.C., BIGGS, H.C., MEISSNER, H.H. \& BASSON, P.A. 1996. The usefulness of faecal phosphorus and nitrogen in interpreting differences in live-mass gain and the response to $P$ supplementation in grazing cattle in arid regions. Onderstepoort J. Vet. Res. 63: 121-126.

GRANT, C.C., MEISSNER, H.H. \& SCHULTHEISS, W.A. 1995. The nutritive value of veld as indicated by faecal phosphorus and nitrogen and its relation to the condition and movement of prominent ruminants during the 1992-1993 drought in the Kruger National Park. Koedoe 38: 17-31.

GRANT, C.C., PEEL, M.J.S., ZAMBATIS, N. \& VAN RYSSEN, J.B.J. 2000. Nitrogen and phosphorus concentration in faeces: an indicator of range quality as a practical adjunct to existing range evaluation methods. Afr. J. Range Forage Sci. 17: 81-92.

HOBBS, N.T. 1987. Faecal indices to dietary quality: a critique. J. Wildl. Manage. 51: 317-320.

HOLECHEK, J.L., VAVRA, M. \& ARTHUN, D. 1982. Relationships between performance, intake, diet nutritive quality and fecal nutritive quality of cattle on mountain range. J. Range. Manage. 35: 741-744.

HOLECHEK, J.L., GALYEAN, M.L., WALLACE, J.D. \& WOFFORD, H. 1985. Evaluation of faecal indices for predicting phosphorus status of cattle. Grass Forage Sci. 40: 489-492.

IRWIN, L.L., COOK, J.G., McWHIRTER, D.E., SMITH, S.G. \& ARNETT, E.B. 1993. Assessing winter dietary quality in bighorn sheep via fecal nitrogen. J. Wildl. Manage. 57: 413-421.

LEISTNER, O.A. 1967. The plant ecology of the southern Kalahari. Mem. Bot. Surv. S. Afr. 38: 1-172.

LEITE, E.R. \& STUTH, J.W. 1990. Value of multiple fecal indices for predicting diet quality and intake of steers. J. Range. Manage. 43: 139-143.

LESLIE Jr, D.M. \& STARKEY, E.E. 1985. Fecal indices to dietary quality of cervids in old-growth forests.
J. Wildl. Manage. 49: 142-146.

LESLIE Jr, D.M. \& STARKEY, E.E. 1987. Fecal indices to dietary quality: a reply. J. Wildl. Manage.51:321-325.

McDOWELL, L.R. 1992 Minerals in animal and human nutrition. Academic Press, San Diego.

McDOWELL, L.R. 1997 Minerals for grazing ruminants in tropical regions, 3rd edn. University of Florida, Gainsville, Florida.

MACLEOD, S.B., KERLEY, G.I.H. \& GAYLARD, A. 1996. Habitat and diet of bushbuck Tragelaphus scriptus in the Woody Cape Nature Reserve: observations from faecal analyses. S. Afr. Wildl. Res. 26: 19-25.

MBATHA, K.R. \& WARD, D. 2006. Using faecal profiling to assess the effects of different management types on diet quality in semi-arid savanna. Afr. J. Range Forage Sci. 23: 29-38.

MILLS, M.G.L. \& RETIEF, P.F. 1984. The response of ungulates to rainfall along the riverbeds of the southern Kalahari. Koedoe (Suppl.): 129-141.

SKARPE, C. \& BERGSTRÖM, R. 1986. Nutrient content and digestibility of forage plants in relation to plant phenology and rainfall in the Kalahari, Botswana. J. Arid Env. 11: 147-164.

STAPELBERG, F.H. 2007. Feeding ecology of the Kalahari springbok Antidorcas marsupialis in the Kgalagadi Transfrontier Park, South Africa. M.Sc. dissertation, University of Pretoria, Pretoria.

STAPELBERG, F.H., VAN ROOYEN, M.W. \& BOTHMA, J. DU P. In press. Seasonal nutrient fluctuation in selected plant species in the Kalahari. Afr. J. Range Forage Sci.

TOTOLO, O. \& CHANDA, R. 2003. Environmental change and stability issues in the Kalahari region. J. Arid Env. 54: 257-259.

THORNTON, R.F., BIRD, P.R., SOMERS, M. \& MOIR, R.J. 1970. Urea excretion in ruminants. III. The role of the hind-gut (caecum and colon). Aust. J. Agric. Res. 21: 345-354.

VAN DER WAAL, C., SMIT, G.N. \& GRANT, C.C. 2003. Faecal nitrogen as an indicator of the nutritional status of kudu in a semi-arid savanna. S. Afr. J. Wildl. Res. 33: 33-41.

VAN ROOYEN, N. \& VAN ROOYEN, M.W. 1998. Vegetation of the south-western arid Kalahari: an overview. Trans. Royal Soc. S. Afr. 53: 113-140.

VORSTER, F. 1996. Habitat evaluering vir springbokke (Antidorcas marsupialis). Ph.D. thesis, University of Pretoria, Pretoria.

WOFFORD, H., HOLECHEK, J.L., GALYEAN, M.L., WALLACE, J.D. \& CARDENAS, M. 1985. Evaluation of fecal indices to predict cattle diet quality. J. Range. Manage. 38: 450-454.

WRENCH, J.M., MEISSNER, H.H. \& GRANT, C.C. 1997. Assessing diet quality of African ungulates from faecal analyses: the effect of forage quality, intake and herbivore species. Koedoe 40: 125-136.

WRENCH, J.M., MEISSNER, H.H., GRANT, C.C. \& CASEY, N.H. 1996. Environmental factors that affect the concentration of $P$ and nitrogen in faecal samples collected for the determination of nutritional status. Koedoe 39: 1-6.

Corresponding Editor: E.Z. Cameron 